\title{
ASSESSMENT OF THE IMPACT OF AUTOMATIC MILKING ON THE SELECTED PARAMETERS OF DAIRY COWS WELFARE
}

\author{
Miloslav ŠOCH ${ }^{*}{ }^{1}$, Otakar FIALA*, Jana ŠŤASTNÁ*, Jan BROUČEK**, \\ Petr TEJML*, Luboš SMUTNÝ*, Šárka SMUTNÁ*, Bohuslav ČERMÁK*, \\ Luboš ZÁBRANSKÝ*, Anna ŠIMKOVÁ*, Kateřina ŠVEJDOVÁ*, Marcela \\ RAABOVÁ*, Václav PÁLKA* \\ * University of South Bohemia in České Budějovice \\ ** Animal Production Research Centre Nitra, Slovak Republic
}

\begin{abstract}
: the aim of study was to find out the influence of milking by automatic milking system (AMS) on the physiological needs of dairy cows within 30 minutes after milking. Ethological study covered the needs of feed intake, water intake and need of lying down. The need of feed intake in 30 minutes after milking was found at $75.51 \%$ of dairy cows in the barn with AMS. The need of water intake was found at $41.79 \%$ of dairy cows. The percentage of cows, which needed to lie down after milking, was $3.7 \%$.
\end{abstract}

Keywords: cows, milking; automatic milking system; ethological study; feed intake

\section{INTRODUCTION}

Breeders are trying to improve the level of well-being not only in dairy cows, but also with ourselves. One of the big helpers in achieving this goal may be milking by automatic milking system - milking robot. From the perspective of farmers the most required aim is to eliminate the demanding work of milkers and to save time that can be used for other activities. The other

\footnotetext{
${ }^{1}$ University of South Bohemia in the Czech Budejovice, Faculty of Agriculture, Department of Veterinary Sciences and Product Quality, 370 05, Studentská 13, České Budějovice, Czech Republic, Phone: +420 389032 428, E-mail: soch@zf.jcu.cz
}

Vol. XVII (2013), no.2 
reason is to reduce the number of employees, and thus financial savings, but it is necessary to calculate the increased costs of energy consumption (Upton et al., 2011), (Vorríšková, 2001). The aim of study was to find out the influence of milking by automatic milking system (AMS) on the physiological needs of dairy cows within 30 minutes after milking. Ethological study covered the needs of feed intake, water intake and need of lying down. It is stated, that cattle prefer calm water surface, and therefore watering troughs are more suitable than drinkers and that cows can drink 75 130 litres of water depending on the type of feed ration, lactation and climatic conditions. The highest intensity of water intake - up to $40 \%$ - takes place within two hours after milking (Hofírek, 2009). Some authors state, that $41.05 \%$ of cows need water in the period of 30 minutes after milking (Fiala, 2011), (Šoch et al., 2011), (Šoch et al., 2012). others state that up to $46.9 \%$ of dairy cows (Novotná, 2012). According to other authors milking is connected with stress and virtually all of dairy cows are drinking after milking (Bensik et al., 2002), (Bensik et al., 2003), (Šoch, 2005). But all this was found during the process of milking in milking parlours, not in AMS. According to most of authors the main motivation for the feed intake is feeling hungry (Hofírek, 2009), (Voříšková, 2001), (Wagner-Storch, 2003). and the need is higher after milking (Wagner-Storch, 2003). The intensity of feed income within 30 minutes after milking in AMS was determined by the number of dairy cows which in a given time period sought and matured a mixed feeding ration (TMR). Data from previous experiments differ about $80 \%$ (Fiala, 2011), (Novotná, 2012). While we found the difference in feed intake between heifers and cows at higher lactations which had this need higher by $13.6 \%$ (Fiala, 2011) or 9\% (Novotná, 2012). It can be caused by a certain hierarchy within the herd and limited access of submissive individuals, especially younger animals to feeding table (Hofírek, 2009) (Šoch et al., 2012). After milking it is important to keep a cow on her feet for a longer time. Immediately after milking, the teat sphincter is released and the teat canal expanded, so it may be penetrated by environmental bacteria, especially when the bedding is polluted. Within an hour after milking the canal is gradually closed. The prolongation of the period of standing after milking can be influenced by the access to the feed before and after milking. To reduce the inflammation of the mammary gland it is much more important to follow the hygiene of udder before, during and after milking, which provides high-level milking robot (Fiala, 2011), (Tančín et al., 2008). While evaluating the need of lying down within 30 minutes after milking in

Vol. XVII (2013), no.2 
AMS $12.16 \%$ of lied dairy cows were found (Fiala, 2011), (Šoch et al., 2011), (Šoch et al., 2012), while in heifers the need of lying down was by 1 $\%$ higher (Fiala, 2011), (Šoch et al., 2011), (Šoch et al., 2012). The observed difference between heifers and older cows was minimal. Lying down is to a certain extent related with ruminating, which begins approximately 15-17 minutes after finishing the feed intake and it is associated with high energy consumption, when cows are usually lying on their side (Bencsik et al., 2002), (Bencsik et al., 2003), (Šoch, 2005).

\section{MATERIALS AND METHODS}

Experiments were carried out on a farm with free stabling with 61 dairy cows, 38 heifers and 15 calves under 6 months of age. All animals were of Holstein breed, the average annual yield per cow moved around 12,000 litres of milk in the long-term.

AMS (automatic milking system) of company Lely has been in operation since 18.09.2007 at the farm. The main reasons for the acquisition were for the owner the comfort of family and time saving. Feeding in the stable is provided by a mixing and feeding car and takes place once a day always around 6 p.m. The composition of feed ration is regulated according to individual groups of animals and lactating cows are in the robot also given a dose of a mixture according to their performance in the range of 1-8 $\mathrm{kg}(0.4$ $\mathrm{kg} /$ litre of milk). Ration in the milking robot is used both to increase production and quality of milk, and to increase motivation of dairy cows to visit the robot. Watering is provided by watering troughs. In the frame of the survey of physiological needs we conducted three 24hours ethological observations on the farm where cows are milked by AMS (automatic milking system). Overall, physiological needs of 457 pieces of cows within 30 minutes after milking were tested on this farm. For each cow a need of water intake, feed intake and need to lie down were monitored. Using the computer program Lely T4C data on milk yield, duration of milking and frequency of visits were obtained. To process the information we used Microsoft Excel. Differences in the frequency of monitored groups of heifers and other cows in case of need of feed intake, water intake or need to lie down were compared using the $\chi^{2}$ test. Comparison of commercial properties of groups of heifers and other cows were performed using Students t-test in programme Statistika.

Vol. XVII (2013), no.2 


\section{RESULTS AND DISCUSSIONS}

Altogether 457 observations of cows during 30 minutes after leaving the robot were carried out in the experiment. From this total number, there were 150 heifers and 307 cows on the other lactations.

\section{a) Feed intake}

Feed intake (Table 1) was found at $75.71 \%$ of monitored dairy cows, $68 \%$ of heifers and $79.45 \%$ of other dairy cows. In comparison with data of other (Fiala, 2011), (Novotná, 2012), (Šoch et al., 2012), who state in their studies the total feed intake at $81.8 \%$ and $80.8 \%$, our figures observed are lower by $6 \%$, respect. by $5 \%$. This difference can be due to a slight change in a feed ration. Furthermore there is an obvious higher feed intake of dairy cows on other lactations compared with heifers by $11.45 \%$.

In published studies (Fiala, 2011), (Šoch et al., 2011), (Šoch et al., 2012) this difference is $13.6 \%$, alternatively $9 \%$ (Novotná, 2012). Figures recorded in this experiment do not differ considerably very much from the former observations. This difference can be explained in accordance with the reported findings (Šoch et al., 2005) by a higher total performance of cows on other lactations and therefore a possible higher issue of energy during milking. Another reason may be the dominant position of older cows in the herd, which usually spend more time at the trough and according to some authors (Hofírek, 2011), (Šoch, 2005), (Šoch et al., 2012) they prevent by this way to access of submissive individuals. Automatic milking system Lely offers cows a dose of grain mixtures, whose amount depends on the performance of a given cow. This way dairy cows accept the feed also during milking. Despite this fact, most dairy cows observed in the experiment aimed after leaving the AMS to the feeding table with a mixed feeding ration (TMR).b)

Table 1. Feed intake within 30 minutes after milking in specific parts of the day.

\begin{tabular}{|l|l|l|l|l|}
\hline Time period & \multicolumn{1}{|c|}{$\begin{array}{c}\text { 1.observation } \\
(98 \text { feedings })\end{array}$} & $\begin{array}{c}\text { 2.observation } \\
(122 \text { feedings })\end{array}$ & $\begin{array}{c}\text { 3. observation } \\
(126 \text { feedings })\end{array}$ & average \\
\hline $0: 00-6: 00$ & $22.45 \%$ & $25.60 \%$ & $20.63 \%$ & $22.56 \%$ \\
\hline $6: 00-12: 00$ & $19.39 \%$ & $19.67 \%$ & $19.05 \%$ & $19.37 \%$ \\
\hline $12: 00-18: 00$ & $23.47 \%$ & $23.77 \%$ & $23.02 \%$ & $23.42 \%$ \\
\hline $18: 00-0: 00$ & $34.69 \%$ & $31.97 \%$ & $32.54 \%$ & $33.07 \%$ \\
\hline
\end{tabular}

Acta Universitatis Cibiniensis Series E: FOOD TECHNOLOGY

Vol. XVII (2013), no.2 


\section{b) Water intake}

Need of water intake was found at $41.79 \%$ of the whole number of dairy cows, $38.66 \%$ of heifers and $43.32 \%$ of other dairy cows. Other authors (Fiala, 2011), (Šoch et al., 2011), (Šoch et al., 2012) state the total need of water within 30 minutes after milking $41.05 \%$ of cows, respect. $46.9 \%$ (Novotná, 2012). Again, a higher water intake in older cows, about $4.66 \%$ is obvious. This difference is not too high and can be related with a higher performance in older dairy cows (Bencsik et al., 2002), (Bencsik et al., 2003), (Šoch, 2005). In some publications the difference only $1.3 \%$ is quoted (Fiala, 2011), (Šoch et al., 2011), (Šoch et al., 2012), other authors, however, state the reverse difference, namely a higher water intake in heifers, about $15 \%$ (Novotná, 2012).

Table 2. Water intake within 30 minutes after milking in specific parts of the day.

\begin{tabular}{|c|c|c|c|c|}
\hline Time period & $\begin{array}{c}\text { 1. observation } \\
\text { (60 drinkings) }\end{array}$ & $\begin{array}{c}\text { 2. observation } \\
\text { (58 drinkings) }\end{array}$ & $\begin{array}{c}\text { 3.observation } \\
\text { (73 drinkings) }\end{array}$ & average \\
\hline $0: 00-6: 00$ & $18.33 \%$ & $15.52 \%$ & $17.8 \%$ & $16.76 \%$ \\
\hline $6: 00-12: 00$ & $30 \%$ & $37.93 \%$ & $34.24 \%$ & $32 \%$ \\
\hline $12: 00-18: 00$ & $30 \%$ & $17.24 \%$ & $30.14 \%$ & $25 \%$ \\
\hline $18: 00-0: 00$ & $21.67 \%$ & $29.31 \%$ & $17.81 \%$ & $22.93 \%$ \\
\hline
\end{tabular}

\section{c) Need to lie down}

Lying down after milking of dairy cows was observed overall in $3.7 \%$ of the total number of dairy cows, $5.3 \%$ of heifers and $2.9 \%$ of other cows. In the literature (Fiala, 2011), (Šoch et al.,2011), (Šoch et al., 2012) totally $12.16 \%$ of lied cows is quoted; our recorded figures are by $8 \%$ lower. The observed difference between heifers and older cows is $2.4 \%$; the difference is in this number minimal, although some authors say this difference is even lower (Fiala, 2011), (Šoch et al.,2011), (Šoch et al., 2012).

Total number of observed physiological needs within 30 minutes after milking is shown in the following Table 4. Most of the dairy cows (75.1\%) aim after milking to the feeding table with mixed feeding ration (TMR) and less than half of them $(41.79 \%)$ feel the need of water intake and it is despite the fact that the waterhole is located at the exit of the milking robot.

Difference between feed and water intake was $34.31 \%$ and similar differences state also other quoted authors (Fiala, 2011), (Novotná, 2012), (Šoch et al.,2011), (Šoch et al., 2012), (Wagner-Storch, 2003), which does

Vol. XVII (2013), no.2 
not correspond with the findings of the behaviour of dairy cows milked in milking parlours (Bencsik et al., 2002), (Bencsik et al., 2002), (Šoch, 2005), (Šoch et al., 2012), (Tančin et al., 2008). From the total number of 457 observations common feed and water intake within 30 minutes after milking was found in 129 cases, which is $28.23 \%$ of the total. In 111 cases, i.e. 88.6 $\%$ of dairy cows, felt need of water intake earlier. In the literature (Fiala, 2011), (Šoch et al.,2011), (Šoch et al., 2012) $23.63 \%$ of common intake is quoted, it means a similar result. $5.03 \%$ of cows did not feel any need of feed or water intake. Common intake of feed and water and lying down were observed only in 3 cases, lying down and feed intake together only one time and common lying down and drinking in 4 cases.

Table 3. Need to lie down within 30 minutes after milking in specific parts of the day.

\begin{tabular}{|c|c|c|c|c|}
\hline Time period & $\begin{array}{c}\text { 1. observation } \\
(6 \text { lyings down) }\end{array}$ & $\begin{array}{c}\text { 2. observation } \\
\text { (5 lyings down) }\end{array}$ & $\begin{array}{c}\text { 3. observation } \\
\text { (6 lyings down) }\end{array}$ & Average \\
\hline $0: 00-6: 00$ & $50 \%$ & $40 \%$ & $66.67 \%$ & $52 \%$ \\
\hline $6: 00-12: 00$ & $16.67 \%$ & $20 \%$ & $0 \%$ & $12.22 \%$ \\
\hline $12: 00-18: 00$ & $16.67 \%$ & $0 \%$ & $0 \%$ & $5.56 \%$ \\
\hline $18: 00-0: 00$ & $33.33 \%$ & $40 \%$ & $33.33 \%$ & $35.55 \%$ \\
\hline
\end{tabular}

Table 4. Total number of physiological needs within 30 minutes after milking.

\begin{tabular}{|l|l|l|l|}
\hline & \multicolumn{1}{|c|}{ Feed intake } & \multicolumn{1}{|c|}{ Water intake } & \multicolumn{1}{c|}{ Lying down } \\
\hline $\begin{array}{l}\text { Total number of } \\
\text { cows }\end{array}$ & $346(75.71 \%)$ & $191(41.79 \%)$ & $17(3.7 \%)$ \\
\hline Heifers & $102(68 \%)$ & $58(38.66 \%)$ & $8(5.3 \%)$ \\
\hline Other cows & $244(79.45 \%)$ & $133(42.32 \%)$ & $9(2.9 \%)$ \\
\hline
\end{tabular}

\section{CONCLUSIONS}

Influence of milking with an automatic milking system on physiological needs of cows within 30 minutes after milking was determined in a herd of highly performed dairy cows of Holstein breed and at the same time the influence of the age (heifers and older cows) on observed behavioural manifestations was assessed. Feed intake was found in the given observed time period at $75.71 \%$ of the total number of observed dairy cows, $68 \%$ of heifers and $79.45 \%$ of other dairy cows. Need of feed intake after milking

Vol. XVII (2013), no.2 
was higher in older cows, by $11.5 \%$ and according to the performed test it was statistically highly significant $(\mathrm{p}<0.05)$. This difference can be explained by higher performance of cows on other lactations and therefore a possible higher issue of energy during milking. Need of water income was found at $41.79 \%$ of the total number of dairy cows, $38.66 \%$ of heifers and $43.32 \%$ of other dairy cows. The difference was not statistically significant and it can be also related with higher performance of older cows. Lying down after milking was observed at $3.7 \%$ of total number of dairy cows, $5.3 \%$ of heifers and $2.9 \%$ of older cows. This difference is found as statistically highly significant $(\mathrm{p}<0.05)$. It can be explained by a possible higher degree of fatigue and level of stress in heifers after milking. The highest need of feed income was in the daytime between 6 a.m. and midnight, while the lowest one in the morning till noon. The highest need of water income after milking was in the morning between 6 and 12 p.m. and the lowest in the night from midnight till 6 p.m. The highest need of lying down after milking was in the night from 0 till 6 p.m. and the lowest between 12 and 18 a.m. From the perspective of welfare using of automated milking system strengthens the freedom of cows to express their standard behaviour and freedom from fear and depression (anxiety), by allowing free choice of accession to milking.

\section{ACKNOWLEDGEMENTS}

This article was written during realization of the project NAZV QJ1210375 and GAJU 020/2013/Z.

\section{REFERENCES}

1. Bencsik, I., Păcală, N., Bencsik, A. \& Blatnyak E. (2002). Study on Holstein-Friesian cows behavior raised in free-stalls. Buletin USAMV Cluj-Napoca, Vol 57, pag.134-137.

2. Bencsik, I., Păcală, N., Stănculeţ, J. \& Bencsik, A. (2003). Behavior of high producing Holstein-Fresian cows during The Three month of lactation. I-th International Symposium Modern trends in livestock production, Beograd, Yugoslavia.

3. Fiala, O. (2011). Effect of automatic milking on selected parameters of dairy cows welfare. ZF JU České Budějovice. Bakalářská práce. (In Czech).

4. Hofírek, B. (2009). Cattle diseases. Brno: Noviko, 1149 s.

Vol. XVII (2013), no.2 
5. Novotná, I. (2012). Effect of automatic milking on selected parameters of dairy cows welfare. ZF JU České Budějovice. Bakalářská práce. (In Czech)

6. Reece, W. O. (1998). Physiology of domestic animals. 1. vyd. Praha: Grada, 449 s.

7. Šoch, M. (2005). Effect of environment on selected indices of cattle welfare. Scientific monograph. 1. vyd. České Budějovice: Jihočeská univerzita, Zemědělská fakulta. $288 \mathrm{~s}$.

8. Šoch, M., Fiala, O., Brouček, J., Raabová, M., Št’astná, J., Novák, P., Zajíček, P., Štengl, R., Tejml, P. \& Pálka, V. (2011). Dairy cows behaviour by using milking robots. Sborník referátů z mezinárodní konference „Ekológia a veterinárna medicína VIII. “, UVLF v Košiciach, str. $17-22$.

9. Šoch, M., Fiala, O., Brouček, J., Zábranský, L., Pálka, V., Tejml, P., Št’astná, J., Novák, P. \& Zajíček, P. (2012). Effect of milking machine on behavioural manifestations of milking cows. Folia veterinaria, 56, Supplementum II: $62-64$.

10. Šoch, M., Brouček, J., Uhrinčat', M., Tančin, V., Palkovičová, Z., Novák, P., Zajíček, P. \& Podsedníček, M. (2012). Study of behaviour adaptation of dairy cows after regrouping and facility change. Banat's University of Agricultural Sciences and Veterinary medicine Timisoara, Faculty of Animal Science and Biotechnologies, Romania. Scientific Papers: Animal Science and Biotechnologies, 45 (2), p. 335 - 359.

11. Tančin, V. \& Tančinová, D. (2008). Machine milking of cows and milk quality. 1. vyd. Nitra: SCPV, $105 \mathrm{~s}$.

12. Upton, J., O'Riordan, G., O’Brien B. and Fitzgerald, S. (2011). Energy consumption of an automatic milking system. Teagasc, Animal \& Grasslan Research and Innovation Centre, Moorepark, Fermoy, Co. Cork, 2Dept.,Page 44.

13. Voříšková, J. (2001). Ethology of Farm Animals (In Czech).: České Budějovice: JU ZF České Budějovice, 168 pp.

14. Wagner-Storch, A.M. \& Palmer, R.W. (2003). Feeding Behavior, Milking Behavior, and Milk Yields of Cows Milked in a Parlor Versus an Automatic Milking System. Journal of Dairy Science, Volume 86, Issue 4, Pages 1494-1502.

Vol. XVII (2013), no.2 